\title{
PIDANA PERINGATAN DALAM SISTEM PERADILAN PIDANA ANAK
}

\author{
${ }^{1}$ Achmad Ratomi dan ${ }^{2}$ Rismaya Mutiara Lestari \\ 1,2Fakultas Hukum ULM Banjarmasin \\ 1ratomi79ach@gmail.com \\ 2rismayamutiara21@gmail.com
}

\begin{abstract}
The purpose of this study is to analyze the rationale for the adoption of warning crimes in the punishment of children in conflict with the law as contained in Article 71 paragraph (1) part an of Law Number 11 of 2012 concerning the Juvenile Criminal Justice System. This research uses normative or doctrinal legal research, which is a process to find legal rules, legal principles, and legal doctrines to answer legal issues faced so that new arguments, theories, or concepts are obtained as prescriptions in solving problems. From this research, the results show that the rationale for formulating warning punishment as a type of punishment for children is following the implementation of the principles of protection, justice, the best interests of the child, the survival and development of children, proportional, deprivation of freedom as a last resort and avoidance of retaliation. This principle is a principle in the administration of juvenile criminal justice as regulated in Article 2 of the SPPA Law.
\end{abstract}

Keywords: Juvenile Criminal Justice, Warning, Criminal, Law Number 11 of 2012

\section{Abstrak}

Tujuan dari penelitian ini adalah untuk menganalisis dasar pemikiran dianutnya pidana peringatan dalam pemidanaan terhadap anak yang berkonflik dengan hukum sebagaiamana yang terdapat di dalam Pasal 71 ayat (1) huruf a UndangUndang Nomor 11 Tahun 2012 tentang Sistem Peradilan Pidana Anak. Penelitian ini menggunakan jenis penelitian hukum normatif atau doktrinal yaitu suatu proses untuk menemukan aturan hukum, prinsip-prinsip hukum maupun doktrin-doktrin hukum guna menjawab isu hukum yang dihadapi sehingga diperoleh argumentasi, teori atau konsep baru sebagai preskripsi dalam menyelesaikan masalah. Dari penelitian ini diperoleh hasil bahwa dasar pemikirannya dirumuskannya pidana peringatan sebagai salah satu jenis pidana untuk anak adalah sesuai dengan implementasi dari asas pelindungan, keadilan, kepentingan terbaik bagi Anak, kelangsungan hidup dan tumbuh kembang Anak, proporsional, perampasan kemerdekaan sebagai upaya terakhir dan penghindaran pembalasan. Asas ini merupakan asas dalam penyelenggaraan peradilan pidana anak sebagaimana diatur di dalam Pasal 2 UU SPPA.

Kata Kunci: Peradilan Pidana Anak, Peringatan, Pidana, Undang-undang No 11 Tahun 2012 


\section{PENDAHULUAN}

Negara menjamin setiap anak berhak atas keberlangsungan hidup, tumbuh dan berkembang serta berhak atas perlindungan dari kekerasan dan diskriminasi. Kepentingan terbaik bagi anak patut dihayati, sebagai kepentingan terbaik bagi kelangsungan hidup umat manusia.Oleh karena itu, semuanya selalu berupaya agar jangan sampai anak menjadi korban kekerasan, maupun anak terjerumus melakukan perbuatan-perbuatan jahat atau perbuatan tidak terpuji lainnya (Wahyudi, 2011).

Beberapa peristiwa yang muncul sehubungan dengan proses hukum di mana sang korban dan pelaku adalah anak-anak. Pembelaan terhadap anak korban tindak pidana telah menjadi gerakan kolektif yang melibatkan organisasi/aktivis hak-hak anak dan perempuan dan telah menjangkau secara luas elemen kemasyarakatan lainnya dan seringkali mengabaikan sang pelaku yang sebenarnya masih anak-anak. Pada kasus ini, disadari munculnya persoalan dilematis akibat perbenturan kepentingan. Di satu sisi, gerakan tersebut menuntut agar pelaku dihukum seberat-beratnya sebagai efek jera, di sisi lain diantara para pihak tersebut terdapat anak sebagai pelaku tindak pidana yang juga memerlukan perlindungan hukum. Hal ini telah dipertegas di dalam Pasal 59 ayat (2) huruf b Undang-Undang Nomor 23 Tahun 2002 tentang Perlindungan Anak sebagaimana dirubah dengan Undang-Undang Nomor 35 Tahun 2014 tentang Perubahan Atas Undang-Undang Nomor 23 Tahun 2002 tentang Perlindungan Anak dan dirubah kembali dengan Undang-Undang Nomor 17 Tahun 2016 tentang Penetapan Peraturan Pemerintah Pengganti Undang-Undang Nomor 1 Tahun 2016 tentang Perubahan Kedua Atas UndangUndang Nomor 23 Tahun 2002 tentang Perlindungan Anak menjadi UndangUndang (selanjutnya disebut UU Perlindungan Anak) yang berbunyi "Perlindungan Khusus kepada Anak sebagaimana dimaksud pada ayat (1) diberikan kepada: Anak yang berhadapan dengan hukum". Ayat (1) dari pasal tersebut berbunyi "Pemerintah, Pemerintah Daerah, dan lembaga negara lainnya berkewajiban dan bertanggung jawab untuk memberikan Perlindungan Khusus kepada Anak". Anak sebagai pelaku tindak pidana yang secara hukum disebut dengan anak yang berkonflik dengan hukum merupakan salah satu bagian dari apa yang disebut sebagai anak yang berhadapan dengan hukum.

Tujuan diberikannya perlindungan hukum bagi pelaku kejahatan adalah untuk menghormati hak asasi si pelaku agar nasibnya tidak terkatung-katung, adanya kepastian hukum bagi pelaku serta menghindari perlakuan sewenangwenang dan tidak wajar. Sedangkan konsepsi perlindungan anak meliputi ruang lingkup yang luas, dalam arti bahwa perlindungan anak tidak hanya mengenai perlindungan atas jiwa dan raga anak, tetapi mencakup pula perlindungan atas 
semua hak serta kepentingannya yang dapat menjamin prtumbuhan secara wajar, baik secara rohani, jasmani maupun sosialnya sehingga diharapkan dapat menjadi orang dewasa yang mampu berkarya (Wardaya, 2018).

Undang-Undang Nomor 11 Tahun 2012 tentang Sistem peradilan pidana anak (Selanjutnya disebut UU SPPA) merupakan suatu bentuk perlindungan hukum yang diberikan oleh negara melalui kebijakan formulasinya dalam rangka lebih memberikan kepastian hukum dan menjadi pedoman bagi penegak hukum dan elemen masyarakat lainnya. Lahirnya undang-undang tersebut didasarkan pada alasan sebagaimana yang terdapat di dalam konsiderannya yaitu untuk menjaga harkat dan martabatnya, anak berhak mendapatkan pelindungan khusus, terutama pelindungan hukum dalam sistem peradilan.

Sistem peradilan pidana anak akan mengutamakan kesejahteraan anak dan memastikan bahwa reaksi apapun terhadap pelanggar-pelanggar hukum anak akan selalu sepadan dengan keadaan-keadaan, baik pada pelanggarpelanggar hukumnya maupun pelanggaran hukumnya. Jadi menurut Beijing Rules, tujuan penting dalam peradilan anak adalah memajukan kesejahteraan anak (penghindaran sanksi-sanksi yang sekedar menghukum semata) dan menekankan pada prinsip proporsionalitas (Djamil, 2012).

Salah satu bentuk perlindungan hukum bagi anak yang berkonflik dengan hukum adalah bervariasinya jenis-jenis sanksi yang dapat dijatuhkan oleh hakim kepada anak. Hal ini dapat dilihat di dalam Pasal 71 UU SPPA yang berbunyi :

(1) Pidana pokok bagi Anak terdiri atas:

a. Pidana peringatan;

b. Pidana dengan syarat:

1) Pembinaan di luar lembaga;

2) Pelayanan masyarakat; atau

3) Pengawasan.

c. Pelatihan kerja;

d. Pembinaan dalam lembaga; dan

e. Penjara.

(2) Pidana tambahan terdiri atas

a. Perampasan keuntungan yang diperoleh dari tindak pidana; atau

b. Pemenuhan kewajiban adat.

Selain dalam bentuk pidana, pembentuk undang-undang juga memberikan kebebasan kepada Hakim untuk memilih sanksi lain yang lebih ringan yaitu sanksi tindakan. Hal ini sebagaimana yang diatur di dalam Pasal 82 ayat (1) UU SPPA yang berbunyi :

“Tindakan yang dapat dikenakan kepada Anak meliputi: 

a. Pengembalian kepada orang tua/Wali;
b. Penyerahan kepada seseorang;
c. Perawatan di rumah sakit jiwa;
d. Perawatan di LPKS;
e. Kewajiban mengikuti pendidikan formal dan/atau pelatihan yang diadakan oleh pemerintah atau badan swasta;
f. Pencabutan surat izin mengemudi; dan/atau
g. Perbaikan akibat tindak pidana.

Penerapan sanksi tersebut harus diterapkan dengan berpedoman pada ketentuan yang terdapat di dalam Pasal 69 ayat (2) UU SPPA yang berbunyi "Anak yang belum berusia 14 (empat belas) tahun hanya dapat dikenai tindakan". Ini artinya bahwa anak yang telah berusia 14 (empat belas) atau lebih dapat dikenakan tindakan atau pidana. Sedangkan yang berusian kurang dari 14 (empat belas) tahun tidak dapat dikenakan pidana. Dari sekian jenis sanksi baik pidana maupun tindakan yang menjadi perhatian penulis karena sifatnya ringan namun termasuk kategori pidana adalah pidana peringatan. Menurut Pasal 72 UU SPPA, "Pidana peringatan merupakan pidana ringan yang tidak mengakibatkan pembatasan kebebasan anak".

\section{METODE}

Penelitian ini menggunakan jenis penelitian hukum normatif atau doktrinal yaitu suatu proses untuk menemukan aturan hukum, prinsip-prinsip hukum maupun doktrin-doktrin hukum guna menjawab isu hukum yang dihadapi sehingga diperoleh argumentasi, teori atau konsep baru sebagai preskripsi dalam menyelesaikan masalah. Adapun pendekatan yang digunakan penulis dari beberapa pendekatan diatas adalah pendekatan perundangundangan (statute approach). Pendekatan perundangan-undangan adalah pendekatan yang dilakukan dengan menelaah semua undang-undang dan regulasi yang bersangkut paut dengan isu hukum yang ditangani. Undangundang yang digunakan adalah Undang-Undang Nomor 11 Tahun 2012 tentang Sistem Peradilan Pidana Anak.

\section{HASIL PENELITIAN DAN PEMBAHASAN}

Hukum pidana disamping sebagai petunjuk dan alat pengatur manusia, juga sebagai alat kontrol sosial untuk melindungi orang-orang dari tabiat seseorang yang membahayakan agar tidak tergelincir secara keseluruhan atau sebagian dalam tabiat yang membahayakan tersebut (Hidayat, 2010). Oleh karena itu, maka salah satu karakteristik atau sifat dari hukum pidana adalah 
adanya sanksi yang dapat diterapkan kepada orang-orang yang telah melanggar larangan atau mengabaikan anjuran/perintah yang diatur di dalam undangundang. Sanksi di dalam hukum pidana pada umumnya disebut dengan pidana.

Pidana pada hakikatnya merupakan suatu pengenaan nestapa atau penderitaan atau akibat lain yang tidak menyenangkan. Pidana diberikan dengan sengaja oleh orang atau badan yang mempunyai kekuasaan (oleh yang berwenang) kepada orang yang telah melakukan tindak pidana menurut undang-undang (Hidayat, 2010). Di dalam rumusan lainnya dikatakan bahwa pidana adalah penderitaan atau nestapa yang sengaja dibebankan kepada orang yang melakukan perbuatan yang memenuhi unsur syarat-syarat tertentu (Andrisman, 2009). Sedangkan Roslan Saleh menegaskan bahwa pidana adalah reaksi atas delik, dan ini berwujud suatu nestapa yang dengan sengaja dilimpahkan Negara kepada pembuat delik (Chazawi, 2011).

Berdasarkan beberapa pengertian di atas, maka dapat disimpulkan bahwa pidana mengandung unsur-unsur dan ciri-ciri sebagai berikut:

a. Pidana itu pada hakikatnya merupakan suatu pengenaan penderitaan atau nestapa atau akibat-akibat lain yang tidak menyenangkan;

b. Pidana itu diberikan dengan sengaja oleh orang atau badan yang mempunyai kekuasaan (oleh yang berwenang);

c. Pidana itu dikenakan kepada seseorang yang telah mekakukan tindak pidana menurut undang-undang;

d. Pidana itu merupakan pernyataan pencelaan oleh negara atas diri seseorang karena telah melanggar hukum pidana.

Jenis-jenis pidana telah tercantum di dalam Pasal 10 KUHP. Jenis- jenis pidana ini berlaku juga bagi tindak pidana yang tercantum di luar KUHP, kecuali ketentuan undang-undang itu menentukan lain. Menurut Pasal 10 KUHP, jenisjenis pidana dibedakan sebagai berikut:

(1) Pidana Pokok

a. Pidana mati;

b. Pidana penjara;

c. Kurungan;

d. Denda; dan

e. Tutupan (ditambah berdasarkanUndang-Undang Nomor 20 Tahun1946).

(2) Pidana Tambahan
a. Pencabutan hak-hak tertentu;
b. Perampasan barang tertentu; dan
c. Pengumuman putusan hakim. 
Sebagaimana dijelaskan sebelumnya bahwa jenis pidana kepada anak berbeda dengan pidana yang dijatuhkan kepada orang pada umumnya. Jenis pidana yang dapat dijatuhkan kepada anak telah diatur di dalam Pasal 71 ayat (1) UU SPPA. Selain dapat dijatuhi pidana, anak yang berkonflik dengan hukum dapat juga dijatuhi sanksi tindakan. Penerapan jenis pidana ini bersifat alternatif yaitu Hakim dapat memilih sanksi pidana atau sanksi tindakan. Untuk anak yang bersalah melakukan tindak pidana yang usianya telah mencapai 12 tahun tetapi belum 14 tahun hanya dapat dikenakan tindakan. Sedangkan untuk anak yang telah berusia 14 tahun tetapi belum mencapai 18 tahun dapat dikenakana tindakan atau pidana.

Penjatuhan pidana kepada anak harus tetap memperhatikan kesejahteraan anak dan harus berdasarkan pada prinsip proporsionalitas. Hal ini sesuai dengan ketentuan yang terdapat di dalam Rule 5.1 United Nations Standard Minimum Rules for the Administration of Juvenile Justice ("The Beijing Rules") (Aturan Standar Minimum Persatuan Bangsa-Bangsa Untuk Administrati Peradilan Anak (Aturan Beijing). Di dalam ketentuan tersebut dinyatakan bahwa The juvenile justice system shall emphasize the well-being of the juvenile and shall ensure that any reaction to juvenile offenders shall always be in proportion to the circumstances of both the offenders and the offence (Peradilan anak harus menekankan pentinganya kesejahteraan dari remaja dan harus menjamin bahwa seluruh penanganan terhadap para pelaku remaja akan selalu sesuai dengan keadaan, baik keadaan dari pelaku maupun keadaan dari pelanggaran tersebut).

Tujuan pertama dari aturan itu adalah meningkatkan kesejahteraan dari anak. Ini adalah fokus utama dari sistem-sistem hukum dimana anak ditangani dengan melalui pengadilan keluarga atau pejabat administratif, tetapi kesejahteraan anak juga harus ditekankan dalam sistem-sistem hukum yang menganut model peradilan pidana, sehingga dengan demikian ikut berperan dalam menghindari dijatuhkannya sanksi-sanksi yang hanya bersifat menghukum.

Kesejahteraan anak itu penting karena:

a. Anak adalah potensi serta penerus cita-cita bangsa

b. Agar setiap anak mampu memikul tanggung jawab tersebut, maka ia perlu mendapatkan kesempatan untuk tumbuh dan berkembang secara wajar

c. Di dalam masyarakat terdapat anak-anak yang mengalami hambatan kesejahteraan rohani, jasmani, sosial dan ekonomi

d. Anak belum mampu memelihara dirinya

e. Hambatan tersebut akan hilang jika usaha kesejahteraan anak terjamin 
Tujuan kedua adalah "prinsip proporsionalitas". Prinsip ini adalah instrumen yang dikenal luas untuk menghindari adanya sanksi-sanksi yang bersifat menghukum, biasanya disebut dengan istilah ganjaran yang sesuai dengan beratnya pelanggaran. Penanganan para pelaku anak ini harus didasarkan bukan hanya pada beratnya pelanggaran tetapi juga pada keadaankeadaan pribadi. Keadaan pribadi dari si pelaku (misalnya status sosial, keadaan keluarga, kerugian yang diakibatkan oleh pelanggaran itu, serta faktorfaktor lain yang berkaitan dengan keadaan-keadaan pribadi) harus berpengaruh pada proporsionalitas dari penanganan (misalnya dengan mempertimbangkan usaha pelaku untuk mengganti kerugian pada korban atau kemauannya untuk kembali kepada kehidupan yang utuh dan berguna).

Pada intinya, Rule 5 The Beijing Rule ininmenginginkan adanya penanganan yang adil untuk semua perkara pidana anak. Masalah-masalah yang dikemukakan dalam aturan ini bisa membantu untuk mendorong perkembangan dalam dua hal tersebut: jenis-jenis penanganan yang baru dan inovatif sama diharapkannya dengan pencegahan terhadap adanya terlampau meluasnya jaring kontrol sosial terhadap anak.

Berdasarkan pada ketentuan yang terdapat di dalam Rule 5 tersebut, maka pembentuk undang-undang di Indonesia telah mengejawantahkan inti dari tujuan peradilan anak tersebut ke dalam bentuk banyaknya variasi jenis pidana yang dapat dijatuhkan kepada anak. Salah satunya adalah pidana peringatan.

Pidana peringatan ini sebelum lahirnya UU SPPA juga telah dianut oleh UU No. 3 Tahun 1997 tentang Pangadilan Anak. Namun yang membedakan jika di dalam UU No. 3 Tahun 1997 peringatan/teguran merupakan jenis sanksi yang dapat dijatuhkan dalam bentuk menyertai sanksi tindakan sebagaimana diatur di dalam Pasal 24 UU No. 3 Tahun 1997 yang berbunyi :

(1) Tindakan yang dapat dijatuhkan kepada Anak Nakal ialah :

a. mengembalikan kepada orang tua, wali, atau orang tua asuh;

b. menyerahkan kepada negara untuk mengikuti pendidikan, pembinaan, dan latihan kerja; atau

c. menyerahkan kepada Departemen Sosial, atau Organisasi Sosial Kemasyarakatan yang bergerak di bidang pendidikan, pembinaan, dan latihan kerja.

(2) Tindakan sebagaimana dimaksud dalam ayat (1) dapat disertai dengan teguran dan syarat tambahan yang ditetapkan oleh Hakim.

Menurut Penjelasan Pasal 24 ayat (2) UU No. 3 Tahun 1997, Yang dimaksud dengan "teguran" adalah peringatan dari Hakim baik secara langsung terhadap anak yang dijatuhi tindakan maupun secara tidak langsung melalui 
orang tua, wali, atau orang tua asuhnya, agar anak tersebut tidak mengulangi perbuatan yang mengakibatkan ia dijatuhi tindakan. Yang dimaksud dengan "syarat tambahan" misalnya kewajiban untuk melapor secara periodik kepada Pembimbing Kemasyarakatan. Sedangkan menurut Pasal 72 UU SPPA, Pidana peringatan merupakan pidana ringan yang tidak mengakibatkan pembatasan kebebasan anak. Pidana peringatan bagi anak dalam UU SPPA hampir mirip dengan teguran dalam hukum pidana Belanda. Maksud teguran berdasarkan hukum pidana Belanda, yaitu sesuai dengan sifat "teguran", terdiri atas katakata yang bertujuan mengoreksi yang diucapkan oleh hakim kepada terhukum berhubungan dengan peristiwa pidana yang telah dilakukan oleh terhukum. Hukuman teguran tersebut harus dilaksanakan segera tanpa menunggu saat keputusan hakim yang bersangkutan telah memperoleh kekuatan keputusan (Utrecht, 1987).

Dianutnya peringatan sebagai salah satu bentuk/jenis pidana ini merupakan suatu terobosan yang berdasarkan pada beberapa asas penyelenggaraan peradilan pidana anak yang tercantum di dalam UU SPPA. Asas-asas yang mendasari lahirnya pidana peringatan sebagaimana yang tercantum di dalam Pasal 2 UU SPPA adalah :

a. Asas perlindungan

Asas ini meliputi kegiatan yang bersifat langsung dan tidak langsung dari tindakan yang membahayakan Anak secara fisik dan/atau psikis. Pidana peringatan jelas akan menghindarkan anak dari lingkungan yang kurang sehat dan kurang baik serta tetap akan terjalin hubungan kasih sayang antara anak dengan keluarga, teman-temannya dan lingkungan sekolahnya. Penjatuhan pidana peringatan yang diucapkan di hadapan orangtua akan membuat tanggng jawab dan kewajiban orangtua lebih diperhatikan dan dilaksanakan agar anak tidak mengulangi lagi tindak pidana.

b. Asas keadilan

Asas ini menerangkan bahwa setiap penyelesaian perkara Anak harus mencerminkan rasa keadilan bagi Anak. Anak akan merasa lebih adil jika dia menerima sanksi pidana yang tidak mengurangi kebebasannya baik kebebasan dalam bersekolah, bermain maupun berkumpul dengan keluarga.

c. Asas kepentingan terbaik bagi anak

Asas ini menjelaskan bahwa segala pengambilan keputusan harus selalu mempertimbangkan kelangsungan hidup dan tumbuh kembang Anak. Menurut Komite Hak-Hak Anak PBB, untuk menentukan kepentingankepentingan terbaik anak-anak perlu dipertimbangkan "semua unsur yang penting untuk membuat keputusan dalam suatu keadaan tertentu untuk 
seorang anak secara individual atau sekelompok anak." Akibat banyaknya faktor yang harus dipertimbangkan, biasanya proses penilaian melibatkan lebih dari satu ahli atau institusi dan menyatukan berbagai sudut pandang dan bidang keilmuan dan (khususnya) sudut pandang anak-anak.

Prinsip kepentingan terbaik bagi anak (the best interest of the Child) adalah prinsip penting dalam perlindungan anak. Prinsip ini dilegitimasi dalam Convention on the Rights of the Child, 20 November 1989. Dalam konvensi hak-hak anak tersebut, prinsip kepentingan terbaik bagi anak dirumuskan dalam Article 3.1 yang berbunyi :

In all actions concerning children, whether undertaken by public or private social welfare institutions, courts of law, administrative authorities or legislative bodies, the best interests of the child shall be a primary consideration. (Dalam semua tindakan yang menyangkut anak, baik yang dilakukan oleh lembaga-lembaga publik atau swasta kesejahteraan sosial, pengadilan hukum, penguasa administratif atau badan legislatif, kepentingan terbaik bagi anak harus menjadi pertimbangan utama).

Keberadaan Artikel 3 Konvensi Hak-Hak Anak itu sangat penting karena ketentuan tersebut mengakui bahwa para pejabat negara yang bersangkutan harus memberi bobot pada hak anak. Artikel 3 mengandung makna bahwa di semua tindakan mengenai anak, apakah itu diambil oleh lembaga kesejahteraan sosial publik atau swasta, pengadilan, pejabat pemerintah, atau badan-badan legislatif, kepentingan terbaik anak harus menjadi bahan pertimbangan utama. Negara-negara pihak berjanji untuk memastikan agar anak mendapat perlindungan dan pemeliharaan yang diperlukan bagi kesejahteraannya, dengan memperhatikan hak dan kewajiban orang tua, wali atau orang lain yang secara hukum bertanggung jawab atas anak tersebut dan untuk tujuan ini, harus mengambil semua tindakan legislatif dan administratif yang tepat (Smith, dkk, 2010).

d. Asas kelangsungan hidup tumbuh kembang anak

Asas ini merupakan hak asasi yang paling mendasar bagi Anak yang dilindungi oleh negara, pemerintah, masyarakat, keluarga, dan orang tua. Dengan dijatuhi pidana peringatan sudah jelas akan terlaksana tanggung jawab dan kewajiban negara, pemerintah, masyarakat, keluarga dan orangtua dalam pelaksanaan perlindungan anak sebagaimana yang diamanatkan di dalam UU Perlindungan Anak. Dengan dijatuhi pidana peringata anak tetap dalam tumbuh dan kembang secara fisik dan mental. Anak tetap mendapatkan hak-haknya seperi hak pendidikan, hak kesehatan dan kasih sayang dari keluarga dan orangtua. 
e. Asas proporsional

Asas ini memiliki makna bahwa segala perlakuan terhadap Anak harus memperhatikan batas keperluan, umur, dan kondisi Anak. Ini juga sesuai dengan tujuan peradilan anak sebagaimana yang terdapat di dalam The Beijing Rules.

f. Asas perampasan kemerdekaan sebagai upaya terakhir

Pada dasarnya Anak tidak dapat dirampas kemerdekaannya, kecuali terpaksa guna kepentingan penyelesaian perkara. Hal ini sesuai dengan sifat dan karakteritik dari pidana peringatan yaitu tidak bersifat merampas kemerdekaan.

g. Asas penghindaran pembalasan.

Merupakan prinsip menjauhkan upaya pembalasan dalam proses peradilan pidana. Lahirnya pidana peringatan sudah jelas bukan merupakan implementasi dari tujuan pemidanaan yang bersifat absolut/pembalasan. Berdasarkan kajian yang dilakukan oleh berbagai kalangan ahli hukum dikatakan bahwa perkembangan teori pemidanaan cenderung beranjak dari prinsip "menghukum" yang berorientasi ke belakang (backward-looking) ke arah gagasan/ide "membina" yang berorientasi ke depan (forward-looking) (Arief, 1996).

Keberadaan pidana peringatan ini juga sejalan dengan prinsip perlindungan anak yang dikemukakan Anthony M. Platt yang mengatakan bahwa (Marlina 2012):

a. Anak harus dipisahkan dari pengaruh kekerasan dari penjahat dewasa.

b. Anak nakal harus dijauhkan dari lingkungannya yang kurang baik.

c. Perbuatan anak nakal harus diupayakan untuk tidak dihukum, kalaupun dihukum harus dengan ancaman hukuman yang minimal dan bahkan penyidikan tidak diperlukan karena terhadap anak harus diperbaiki bukan dihukum.

d. Terhadap anak nakal tidak ditentukan hukuman baginya, karena menjadi narapidana akan membuat perjalanan hidupnya sebagai mantan orang hukuman.

e. Hukuman terhadap anak hanya dijalankan jika tidak ada lagi cara lain yang lebih baik dijalankan.

f. Penjara terhadap anak dihindarkan dari bentuk penderitaan fisik yang buruk.

g. Program perbaikan yang dilakukan bersifat keagamaan, pendidikan, pekerjaan, tidak melebihi pendidikan dasar.

h. Terhadap narapidana anak diberi pengajaran yang lebih baik menguntungkan dan terarah pada keadaan dunia luar. 
Penulis sependapat dengan pendapat Anthony M. Platt, terutama point ke-7, yaitu program perbaikan bersifat keagamaan dan pendidikan. Hakim bisa saja menjatuhkan pidana peringatan, namun juga menyarankan pada orangtua atau wali si anak untuk memasukkan si anak ke TPA (Tempat Pendidikan AlQur'an) atau lebih rajin mengikuti kebaktian di gereja (sesuai dengan kepercayaan masing-masing).

Sedangkan program perbaikan bersifat pendidikan dapat dimulai dengan memindahkan si anak ke sekolah lain, apabila dinilai pergaulan di sekolah tersebut tidak memberikan dampak positif bagi perilaku anak. Atau menyibukkan si anak dengan les, kursus keterampilan, atau hobi yang bermanfaat, seperti olahraga.

Pemerintah, masyarakat, dan keluarga harus saling membantu untuk memulihkan Anak yang pernah melakukan tindak pidana atau kenakalan. Anak harus didukung agar ia pulih dan dapat menjadi bagian dari masyarakat kembali. Penjatuhan pidana peringatan bukan sekedar untuk menghukum Anak, melainkan untuk memberinya kesempatan agar menjadi pribadi yang lebih baik lagi dan menjadi fasilitas bagi keluarga dan masyarakat untuk memenuhi hak asasi Anak, seperti perhatian dan kasih sayang. Menurut Beijing Rules, tujuan penting dalam peradilan anak sebenarnya adalah memajukan kesejahteraan anak (penghindaran sanksi-sanksi yang sekedar menghukum semata) dan menekankan pada prinsip proporsionalitas.

Alasan untuk menerapkan tindakan non-custodial (tidak merampas kemerdekaan) adalah karena tindakan tersebut dianggap lebih manusiawi dan lebih memperhatikan hak asasi manusia dimana kebebasan manusia dianggap sebagai hak yang mendasar. Demikian pula besarnya biaya, baik secara ekonomis maupun sosial dari pidana penjara sebagai suatu sanksi, efek buruk (baik secara psikologis, emosional, maupun sosial) terhadap pelaku tindak pidana, dan rusaknya kehidupan keluarga dan kehidupan sosial pelaku tindak pidana, sehingga tujuan utama dari sistem peradilan pidana yang adalah resosialisasi dan reintegrasi pelaku tindak pidana ke dalam masyarakat dapat dicapai seoptimal mungkin.

\section{KESIMPULAN}

Landasan pemikiran dianutnya pidana peringatan di dalam sistem peradilan pidana anak merupakan suatu langkah yang maju dalam menjamin pelaksanaan perlindungan anak. Walaupun sanksi peringatan ini bukan yang pertama untuk anak yang berkonflik dengan hukum, namun dicantumkannya peringatan sebagai salah satu jenis pidana dalam hukum positif Indonesia merupakan sebagai jaminan dan lebih memperkuat bagi Hakim untuk 
menjatuhkan pidana yang berkeadilan dan berdasarkan kepada Ketuhanan Yang Maha Esa. Pidana peringatan yang tercantum di dalam Pasal 71 ayat (1) huruf a Undang-Undang Nomor 11 Tahun 2012 tentang Sistem Peradilan Pidana Anak (UU SPPA) merupakan implementasi dari beberapa asas penyelenggaraan peradilan pidana anak sebagai dimaksud di dalam Pasal 2 UU SPPA. Dari 10 asas yang ada 7 asas yang mendasari dianutnya pidana peringatan yang dapat dijatuhkan kepada anak yang berkonflik dengan hukum. Ketujuh asas tersebut adalah pelindungan, keadilan, kepentingan terbaik bagi Anak, kelangsungan hidup dan tumbuh kembang Anak, proporsional, perampasan kemerdekaan sebagai upaya terakhir dan penghindaran pembalasan.

\section{DAFTAR PUSTAKA}

Andrisman, Tri. (2009). Asas-Asas dan Dasar Aturan Hukum Pidana Indonesia, Bandar Lampung: Unila.

Arief, Barda Nawawi. (1996). Kebijakan Legislatif dalam penaggulangan kejahatan dengan Pidana Penjara, Semarang : Badan Penerbit UNDIP.

Chazawi, Adami. (2011). Pelajaran Hukum Pidana I, Jakarta: RajaGrafindo Persada.

Djamil, M. Nasir. (2012). Anak Bukan Untuk Dihukum, Jakarta: Sinar Grafika.

Hidayat, Bunadi. (2010). Pemidanaan Anak Dibawah Umur. Bandung: PT Alumni.

Manunggal Kusuma Wardaya. Perlindungan Terhadap Anak yang Melakukan Tindak

Pidana.https://manunggalkusumawardaya.wordpress.com/2010/07/0 7/perlindungan-terhadap-anak-yang-melakukan-tindak-pidana/.

Diakses pada 05/05/2018.

Marlina. (2012). Peradilan Pidana Anak di Indonesia. Bandung: Reflika Utama.

Rhona K.M. Smith, dkk. (2010). Hukum Hak Asasi Manusia. Yogyakarta: Pusat Studi Hak Asasi Universitas Islam Indonesia (PUSHAM UII).

Undang-Undang Republik Indonesia Nomor 23 Tahun 2002 tentang Perlindungan Anak.

Undang-Undang Republik Indonesia Nomor 11 Tahun 2012 tentang Sistem Peradilan Pidana Anak. 
Undang-Undang Republik Indonesia Nomor 35 Tahun 2014 tentang Perubahan Atas Undang-Undang Nomor 23 Tahun 2002 tentang Perlindungan Anak.

United Nations Standard Minimum Rules for the Administration of Juvenile. Justice ("The Beijing Rules"), 29 November 1985.

Utrecht. (1987). Hukum Pidana II, Surabaya : Pustaka Tinta Mas.

Wahyudi, Setya. (2011). Implementasi Ide Diversi Dalam Pembaruan Sistem Peradilan Pidana Anak di Indonesia, Yogyakarta: Genta Publishing.

Wikipedia. Kepentingan-Kepentingan Terbaik Anak. https://id.wikipedia.org/wiki/Kepentingan-kepentingan_terbaik_anak. Diakses pada 05/05/2018. 